\title{
Clomiphene-Metformin in Comparison with Letrozole-Metformin in Overweight Infertile Women with PCOS
}

\section{Ghoneim BM, Farahat MA, El-Badry AM, and El-Gharib MN*}

Departments of Obstetrics \& Gynecology and Radiology, Faculty of Medicine, Tanta University, Egypt.

*Corresponding Author: Mohamed Nabih EL-Gharib, MB, BCH (Hon); DGO; DS; Professor of Obstetrics \&Gynecology, Faculty of Medicine, Tanta University Tanta, Egypt.

Received date: January 11, 2020; Accepted date: January 18, 2020; Published date: January 23, 2020

Citation: Ghoneim BM, Farahat MA, EL-Badry AM, and EL-Gharib MN. (2020) Clomiphene-Metformin in Comparison with LetrozoleMetformin in Overweight Infertile Women with PCOS. Obstetrics Gynecology and Reproductive Sciences, 4(1): DOI:10.31579/2578-8965/037

Copyright: () 2020 Mohamed Nabih EL-Gharib, This is an open access article distributed under the Creative Commons Attribution License, which permits unrestricted use, distribution, and reproduction in any medium, provided the original work is properly cited.

\section{Abstract:}

Background: polycystic ovarian syndrome (PCOS) is a common cause of infertility and is associated with chronic anovulation and hyperandrogenemia. Clomiphene citrate (CC) is still the first-line therapy for ovulation induction in these patients. Metformin, a biguanide, has been used to treat insulin resistance in women with PCOS. Furthermore, many reports confirmed that the addition of metformin to CC in the CC-resistant PCOS was highly effective in achieving ovulation. Letrozole, an aromatase inhibitor, has attracted attention for a long time to induce ovulation.

Aim of the work: In the current study, we aimed to compare the effect of administration of combined metforminClomiphene Citrate to that of combined metformin-letrozole in the induction of ovulation in infertile overweight women with PCOS. 40 infertile overweight cases with PCO were included.

Methods: Sixty participants had received metformin in aggregate with both CC (100 mg) or and similar number received letrozole $(5 \mathrm{mg}$ ) plus metformin for 5 days starting from 3 rd day of their menstrual cycle.

Results: The cumulative pregnancy rate CC-metformin was $21.66 \%$ and letrozole-metformin was $25 \%$, the difference is insignificant.

Conclusion: CC and letrozole are similarly viable in the treatment of overweight women with PCOS, when joined with metformin treatment.

Running title

CC plus metformin versus letrozole plus metformin in treating PCO

Key words: PCOS; Clomiphene citrate; Letrozole, Pregnancy rate; Infertility

\section{Introduction}

Clomiphene citrate (CC) has been the mainline remedy to strengthen different follicular progression and ovulation. [1] CC by going about as antiestrogen on the central fearful framework, assembles the beat repeat of FSH and LH and gives a moderate gonadotropin lift to the ovary, and thusly over-coming ovulatory disrupting impacts. In spite of the way that CC is definitely not hard to use and achieves ovulation in numerous patients (57-91\%), the pregnancy rates are disappointing (27-40\%). It is an immediate aftereffect of the hostile effects of CC generally on the nature of the cervical organic liquid and the endometrial improvement during the prompting. [2]

Letrozole inhibits the aromatase from making estrogens. Their instrument is release of the hypothalamic-pituitary center from estrogenic negative contribution, thusly growing gonadotropin release and occurring in affectation of ovarian follicles. [3] What's locally affects ovary and by androgen collection in-wrinkles follicle affectability to FSH. [4]

Aromatase changes over androstenedione to estrone and testosterone to estradiol. Its activity can be outlined in a couple of tissues, tallying the ovaries, cerebrum, placenta, fat tissue, muscle, liver, bosoms and estrogen subordinate bosom malignant growth. Aromatase is conveyed in a tissue specific way. This synthetic is essentially imparted inside the ovaries of premenopausal women. AIs foresee the aromatase from making estrogens by focused reversible authority to the heme of its cytochrome P450 unit. [5] Letrozole has been demonstratedto be viable, in initiating ovulation and pregnancy in ladies with anovulatory PCOS and deficient CC reaction [6] and improving ovarian reaction to FSH in poor responders. [7] Letrozole has less symptoms than $\mathrm{CC}$ and 
gonadatropins, for example, various pregnancies and OHSS. [8] Metformin is the most prepared and one of the premier convincing verbal prescriptions for type 2 diabetes. From the start, metformin was supported for patients with blocked glucose opposition at the recently settled tendency time frame; regardless more starting late its use was stretched out to various of the PCOS patients and for the total length of pregnancy. [9]

It diminishes hepatic gluconeogenesis and attack discharge, weight get and doesn't increase the opportunity for hypoglycemia. For PCOS patients and patients with type-II diabetes. Metformin is routinely given as a solitary expert to incite ovulation or as an assistant to readiness treatment some time as of late origination just as during the total course pregnancy. For patients with gestational diabetes mellitus metformin was given off an impression of being as viable and as secure as insult in the pregnancy. [10]

This study aims to compare the effect of administration of combined metformin-Clomiphene Citrate to that of combined metformin-letrozole in induction of ovulation in infertile overweight women with PCOS.

\section{Patients and Methods}

This prospective randomized study was conducted at the department of Obstetrics \& Gynecology in Tanta University and AlSanta Central Hospitals during one year starting on March 2017.

\section{Subjects:}

The study included a total of 120 overweight women complaining of polycystic ovary syndrome and attending infertility outpatient clinic of Tanta University Hospital, from January 2017 to December 2019 for the treatment of infertility. All women included in the study gave written informed consent after proper counseling.

\section{Inclusion criteria:}

All patients fulfilled the following inclusion criteria:

- Age 18-30 years.

- Polycystic ovarian syndrome women according to Rotterdam Criteria 2003.(11)

\section{Exclusion criteria:}

1. Patients with a history of cardiovascular disease, diabetes or liver, and kidney failure were excluded.

2. Similarly, patients whose partner's sperm count was less than 20 million/ ml and sperm motility less than $20 \%$ were also not included in the study.

3. Patients who had undergone surgical treatment of infertility.

4. Recent history of ovulatory inducing drugs within the last 3 months.

The patients were divided randomly into two groups through a series of blind envelopes numbered from 1 to 120. Each patient was invited to pull out an envelope and was placed in either:

- Group A: Metformin-Clomiphene citrate group (envelopes number 1-60).

- Group B: Metformin- Letrozole group (envelopes number 61$120)$.

\section{Methods}

Informed written consents were obtained from the patients participating in this study after informing them about aims of study, the steps of study, drugs given and the capability to withdraw at any time.

I. Patient preparation: History taking including, clinical examination, transvaginal ultrasound examination, estimation of serum progesterone on days 21-23 of the cycle.

II. Induction of ovulation: All patients of both groups were received $1500 \mathrm{mg}$ metformin $\mathrm{HCl}$ daily, $500 \mathrm{mg}$ three times a day (Cidophage; Chemical Industries Development, Cairo, Egypt). Also, the patients of the metformin- clomiphene citrate group (CC Group) received 100 mg clomiphene citrate (Clomid; Global Napi Pharmaceuticals, Cairo, Egypt) for 5 days starting from 3rd day of their menstrual cycle, and those in the metformin-letrozole group (letrozole Group) received 5 mg letrozole (Letrozole, Technopharma, Cairo, Egypt) for 5 days from 3rd day of their menstrual cycle. The condition of the ovaries was determined by transvaginal sonography every other day from the 10 th of the cycle.

The hCG (a total of 10,000 IU IM, Choriamon; IBSA, Lugano, Switzerland) was given when one follicle measuring at least $18 \mathrm{~mm}$ was found. Patients were advised to have intercourse every other day for one week, starting 24-36 h after receiving HCG. The patients continued treatment for three successive cycles using the same protocol.

III. Follow up: Follicle monitoring, and endometrial thickness measurement were done with the help of transvaginal sonography serially starting from the 6th day of the drug administration when at least one follicle reached maturity $(>18 \mathrm{~mm})$. Confirmation of the pregnancy was done through urine test using a pregnancy test kit as well as through transvaginal sonography. After confirmation of pregnancy, these patients were followed up \& treated as antenatal cases. Metformin was continued until 28 weeks. The two groups were compared to each other as regards: The occurrence of ovulation which was be evaluated by folliculometry and progesterone level. Statistical methods: The data were transferred to IBM cards using an IBM personal computer and analyzed with the Statistical Program for Social Sciences V11.0 (SPSS Inc, Chicago, IL) Descriptive statistics comprised the mean and standard deviation (SD). Analytical statistics comprised the student's t-test to make comparisons between

Independent quantitative means, and the chi-square test ( ) to make comparisons between the different groups with regard to qualitative data. The chosen level of significance was $\mathrm{p}<0.05$ in all studies. The p- value less than 0.05 were considered to be significant and the confidence interval for odds ratio was set at $95 \%$.

\section{Results}

This prospective randomized study was conducted on 120 infertile overweight cases with PCOS in the department of Obstetrics \& Gynecology in Tanta University and Al-Santa Central Hospital. In the current study, there was no statistically significant difference between both groups as regards age or duration of infertility (mean 
age was $26.40 \pm 5.20$ years and mean duration of infertility was 2.90 \pm 1.40 years in CC group and mean age was $26.50 \pm 5.10$ years and mean duration of infertility was $2.88 \pm 1.21$ years in letrozole group. As regard BMI mean BMI was 27.50 \pm 1.43 in CC group and mean BMI was 27.45 \pm 1.36 in letrozole group. As regard No. of cycles was 59 cycles in CC group and 57 cycles in letrozole group as depicted in table (1).

\begin{tabular}{|c|c|c|c|c|c|}
\hline \multirow{2}{*}{ Item } & \multicolumn{2}{|c|}{$\begin{array}{c}\text { CC Group } \\
\text { (n= 60) }\end{array}$} & \multicolumn{2}{c|}{$\begin{array}{c}\text { Letrozole Group } \\
\text { (n=60) }\end{array}$} & P value \\
\cline { 2 - 6 } & Mean & SD & Mean & SD \\
\hline Age (years) & 26.40 & 5.20 & 26.50 & 5.10 & 0.916 \\
\hline Duration of infertility & 2.90 & 1.40 & 2.88 & 1.21 & 0.933 \\
\hline
\end{tabular}

P: $p$ value for comparing between the two studied groups

*: Statistically significant at $\mathrm{p} \leq 0.05$

As regards to effect of treatment on ovulation: CC group reported 33 cases (55.0\%) ovulation at the first cycle after treatment, increased to 42 cases $(70.0 \%)$ at the second cycle and to 54 cases $(90.0 \%)$ at the third cycle. On the other hand, Letrozole group reported 36 cases $(60.0 \%)$ ovulation at first cycle after treatment, which increased to 48 cases $(80.0 \%)$ at the second cycle and 51 cases $(85.0 \%)$ at the end of the third cycle. Correspondingly, CC group achieved a cumulative ovulation rate of $74.1 \%$ while Letrozole group achieved $77.6 \%$. In conclusion both drugs affected ovulation nearly to the same extent as shown in table (2).

\begin{tabular}{|c|c|c|c|c|l|}
\hline \multirow{2}{*}{ Ovulation } & \multicolumn{2}{|c|}{$\begin{array}{c}\text { CC Group } \\
\text { (n= 60) }\end{array}$} & \multicolumn{2}{c|}{$\begin{array}{c}\text { Letrozole Group } \\
\text { (n= 60) }\end{array}$} & \multirow{2}{*}{ P value } \\
\cline { 2 - 5 } & $\mathrm{N}$ & $\%$ & $\mathrm{~N}$ & \\
\hline First Cycle & 33 & 55 & 36 & 60 & 0.581 \\
\hline Second Cycle & 42 & 70 & 48 & 80 & 0.208 \\
\hline $\begin{array}{c}\text { Third Cycle } \\
\text { Cumulative } \\
\text { ovulation cycles }\end{array}$ & 54 & 90 & 51 & 85 & 0.410 \\
\hline
\end{tabular}

Table 2: Effect of treatment on ovulation in the studied groups

P: p value for comparing between the two studied groups

*: Statistically significant at $\mathrm{p} \leq 0.05$

Concerning the mean number of follicles, there is no statistically significant difference in number of follicles in the ovaries of both groups after treatment. In CC group, the mean variety of vesicle was $1.24 \pm 0.48$ at the first cycle, elevated to be $1.31 \pm 0.71$ at the second cycle, and to $1.42 \pm 0.64$ at the third cycle.
Whereas in letrozole group, mean number of follicles was $1.33 \pm$ 0.52 at the first cycle, elevated to $1.37 \pm 0.75$ at the second cycle and $1.40 \pm 0.70$ at the third cycle. There was no statistical difference between the two studied groups as represented in table (3). 


\begin{tabular}{|l|l|l|l|l|l|l|l|}
\hline \multirow{2}{*}{ No. of follicles } & \multicolumn{3}{|c|}{$\begin{array}{c}\text { CC Group } \\
\text { (n= 60) }\end{array}$} & \multicolumn{2}{c|}{\begin{tabular}{c}
\multirow{2}{*}{ P value } \\
(n= 60)
\end{tabular}} \\
\cline { 2 - 7 } & Mean & SD & No. & Mean & SD & No. & \\
\hline First Cycle & 1.24 & 0.48 & 33 & 1.33 & 0.52 & 36 & 0.7297 \\
\hline Second Cycle & 1.31 & 0.71 & 42 & 1.37 & 0.75 & 48 & 0.6624 \\
\hline Third Cycle & 1.42 & 0.64 & 54 & 1.40 & 0.70 & 51 & 0.7533 \\
\hline
\end{tabular}

Table 3: Effect of treatment on the number of follicles in studied groups

P: $p$ value for comparing between the two studied groups

*: Statistically significant at $\mathrm{p} \leq 0.05$

In connection with the mean follicular diameter across, there is no factually huge distinction in mean follicular width (MFD) in the two groups. In CC group, it was $18.38 \pm 2.03 \mathrm{~mm}, 17.49 \pm 2.45 \mathrm{~mm}$ and $19.12 \pm 3.21 \mathrm{~mm}$ at the first, second and third cycles respectively, while in Letrozole group,

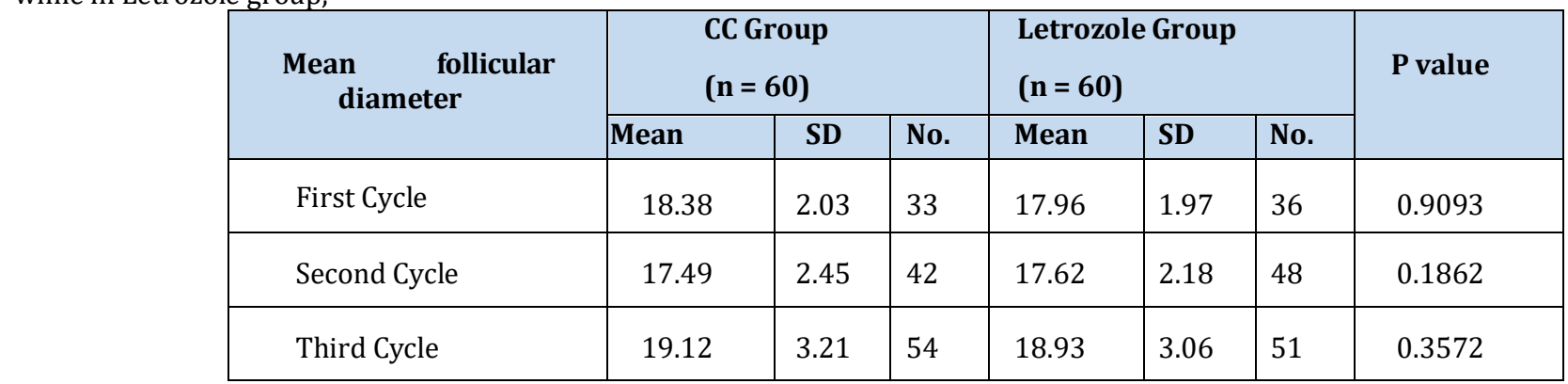

Table 4: Impact of treatment on the mean follicular width (MFD) in studied groups

P: $p$ value for comparing between the two studied groups

$*$ : Statistically significant at $\mathrm{p} \leq 0.05$

Regarding the number of follicles $>18 \mathrm{~mm}$ in both groups, there was no statistically significant difference between studied groups. In CC group the average number of follicles measuring $>18 \mathrm{~mm}$ was the corresponding values was $17.96 \pm 1.97 \mathrm{~mm}, 17.62 \pm 2.18 \mathrm{~mm}$ and $18.93 \pm 3.06 \mathrm{~mm}$ at first, second and third cycles respectively. There was insignificant difference between both groups as displayed in table (4).

\begin{tabular}{|l|l|l|l|l|l|l|l|}
\hline \multirow{2}{*}{$\begin{array}{l}\text { No. of follicles } \\
>\mathbf{1 8 ~ m m . ~}\end{array}$} & \multicolumn{3}{|c|}{$\begin{array}{c}\text { CC Group } \\
\text { (n= 60) }\end{array}$} & \multicolumn{2}{c|}{\begin{tabular}{c}
\multirow{2}{*}{ P value } \\
(n= 60)
\end{tabular}} \\
\cline { 2 - 8 } & Mean & SD & No. & Mean & SD & No. & \\
\hline First Cycle & 1.02 & 0.48 & 33 & 1.11 & 0.50 & 36 & 0.6226 \\
\hline Second Cycle & 0.95 & 0.49 & 42 & 1.03 & 0.54 & 48 & 0.7711 \\
\hline Third Cycle & 1.24 & 0.43 & 54 & 1.16 & 0.53 & 51 & 0.9945 \\
\hline
\end{tabular}

Table 5: Effect of treatment on the number of follicles $>18 \mathrm{~mm}$

P: $p$ value for comparing between the two studied groups

*: Statistically significant at $\mathrm{p} \leq 0.05$

There was insignificant difference between both groups.

Table (6) illustrates that there was no statistically significant difference was found between $\mathrm{CC}$ and letrozole groups as regards the

follicular diameter. On the contrary, there was significant increase in Letrozole group than CC group as regard Cumulative Endometrial thickness as displayed in (table 6). 


\begin{tabular}{|c|c|l|l|l|l|l|l|}
\hline & \multicolumn{3}{|c|}{$\begin{array}{c}\text { CC Group } \\
\text { (n= 60) }\end{array}$} & \multicolumn{2}{c|}{$\begin{array}{c}\text { Letrozole Group } \\
\text { (n= 60) }\end{array}$} & P value \\
\cline { 2 - 8 } & Mean & SD & No. & Mean & SD & No. & \\
\hline Cum. No. of follicles & 1.33 & 0.52 & $129 / 180$ & 1.37 & 0.63 & $135 / 180$ & 0.9283 \\
\hline $\begin{array}{c}\text { Cum. Mean follicular } \\
\text { diameter }\end{array}$ & 18.34 & 2.73 & $129 / 180$ & 18.21 & 2.58 & $135 / 180$ & 0.3328 \\
\hline Cum no. of fol. > 18 mm. & 1.08 & 0.47 & $129 / 180$ & 1.12 & 0.52 & $135 / 180$ & 0.7801 \\
\hline
\end{tabular}

Table 6: Effect of treatment on cumulative number of follicles, mean follicular diameter, and endometrial thickness between the study

P: $p$ value for comparing between the two studied groups groups

*: Statistically significant at $\mathrm{p} \leq 0.05$

The endometrium was thicker in the group accepting letrozole than in that getting clomiphene citrate (Table 7)

\begin{tabular}{|l|c|c|c|c|c|c|c|}
\hline \multirow{2}{*}{$\begin{array}{c}\text { Endometrial } \\
\text { thickness }\end{array}$} & \multicolumn{3}{|c|}{$\begin{array}{c}\text { CC Group } \\
\text { (n= 60) }\end{array}$} & \multicolumn{2}{c|}{$\begin{array}{c}\text { Letrozole Group } \\
\text { (n= 60) }\end{array}$} & \multirow{2}{*}{ P value } \\
\cline { 2 - 7 } & Mean & SD & No. & Mean & SD & No. & \\
\hline First Cycle & 5.84 & 0.59 & 33 & 7.91 & 0.71 & 36 & $\begin{array}{c}0.921 \\
4\end{array}$ \\
\hline Second Cycle & 7.04 & 0.79 & 42 & 8.94 & 0.69 & 48 & 0.150 \\
\hline Third Cycle & 7.16 & 1.01 & 54 & 10.11 & 0.93 & 51 & 0.264 \\
\hline
\end{tabular}

Table 7: Comparison between the two studied groups according to Endometrial Thickness on day of HCG administration in the three months separately and Cumulative Endometrial thickness.

P: $p$ value for comparing between the two studied groups

*: Statistically significant at $\mathrm{p} \leq 0.05$

On the day of human chorionic gonadotrophin administration. In CC group the endometrial thickness was $5.84 \pm 0.59,7.04 \pm 0.79$, and $7.16 \pm 1.01$ at the first, second and third cycles respectively, while in letrozole group, it was $7.91 \pm 0.71,8.94 \pm 0.69,10.11 \pm 0.93$ at the first, second and third cycles respectively. The difference between both groups was statistically insignificant.

In connection with progesterone level at mid luteal phase, we found

statistically significant increase in progesterone level in Letrozole group than CC group. In letrozole group progesterone values was $8.76 \pm 0.72,8.95 \pm 0.51$ and $9.19 \pm 0.52$ at the first, second and third cycles respectively, while in CC group, the equivalent values were $8.01 \pm 0.98,8.29 \pm 0.87,8.37 \pm 0.84$ at first, second and third cycles respectively as revealed in the table (8).

\begin{tabular}{|c|c|l|l|l|l|l|l|}
\hline \multirow{2}{*}{ Progesterone (ng/ml) } & \multicolumn{3}{|c|}{ CC Group (n=60) } & \multicolumn{3}{c|}{$\begin{array}{c}\text { Letrozole Group } \\
\text { (n= 60) }\end{array}$} & \multirow{2}{*}{ P value } \\
\cline { 2 - 7 } & Mean & SD & No. & Mean & SD & No. & \\
\hline First Cycle & 8.01 & 0.98 & 60 & 8.76 & 0.72 & 60 & 0.00964 \\
\hline Second Cycle & 8.29 & 0.67 & 60 & 8.95 & 0.51 & 60 & 0.01902 \\
\hline Third Cycle & 8.37 & 0.84 & 60 & 9.19 & 0.52 & 60 & 0.00016 \\
\hline
\end{tabular}

Table 8: Comparison between the Letrozole and CC groups according to progesterone (ng/ml) level in the three months P: $p$ value for comparing between the two studied groups *: Statistically significant at $p \leq 0.05$ 
The menses was regular in $65 \%$ of patients in CC group and in 55\% of Letrozole group. Side effects as gastritis and sickness were happened in $5 \%$ of patients in both CC and letrozole groups.

Regarding pregnancy rate (per cycle) in CC and letrozole groups. There was no critical distinction $(=186 \& \mathrm{p}=0.666$ ) between the pregnancy rates per cycles in $\mathrm{CC}$ and letrozole gatherings. The cumulative pregnancy rate in the CC group was $21.66 \%$ versus $25 \%$ for the letrozole group. In CC group, one case got pregnant in The first month, six cases got pregnancy within the second and third months respectively. The corresponding figure relating to the letrozole group were three, six, and six cases got pregnancy within the first, second and third month respectively. $25 \%$ for the letrozole group. In CC group, one case got pregnant in The first month, six cases got pregnancy within the second and third months respectively. The corresponding figure relating to the letrozole group were three, six, and six cases got pregnancy within the first, second and third month respectively.

\section{Discussion}

PCOS is the most prevalent endocrine disorder in the reproductive age of women. In these patients, medications such as clomiphene citrate, letrozole and metformin are used to induce ovulation and overcome infertility [12].

Clomiphene citrate binds to estrogen receptors for prolonged periods i.e. weeks ( 2 weeks) rather than hours as with natural estrogen. This extended binding ultimately depletes estrogen receptors' concentrations by interfering with the normal process estrogen receptors' replenishment and may be responsible for the peripheral antiestrogenic effect of clomiphene citrate on the endometrium and cervix [13]

Letrozole is a nonsteroidal reversible, competitive aromatase inhibitor that is highly potent and selective. Letrozole has a half-life of about 45 hours [14].

The proposed mechanisms of ovarian stimulation by letrozole are a central effect on releasing the pituitary-hypothalamic axis from estrogen negative feedback and a local ovarian effect blocking androgen conversion to estrogen, with the concomitant accumulation of androgens inside the ovary, augmenting the follicular FSH receptor expression, and promoting folliculogenesis [15].

Metformin is an oral anti-diabetic drug from biguanides class used for the treatment of type II diabetes mellitus and acts as Insulinsensitizing agents. Metformin is a safe and effective drug that is used for the treatment of PCOS patients. Metformin improves peripheral insulin sensitivity by reducing hepatic glucose production and increasing target tissue sensitivity to insulin. It also decreases androgens in both lean and obese women, leading to increased rates of spontaneous ovulation. Metformin may be used alone or in concert with other medications such as clomiphene citrate, it has been shown to increase the ovulatory response to clomiphene citrate in patients who were previously clomiphene-resistant [16].

The contemporary study was performed to compare the efficaciousness of combined metformin-clomiphene citrate thereto of metformin-letrozole in the induction of ovulation in infertile overweight ladies with PCOS.

In the present study, we found that the mean age was $26.40 \pm 5.20$ years for group A and $26.50 \pm 5.10$ years for group B. The BMI was
$27.50 \pm 1.43$ for the group compared with $27.45 \pm 1.36$ for group B. The mean duration of infertility was $2.90 \pm 1.40$ years for group A and $2.88 \pm$

1.21 years for group B. There was no statistically significant difference between the two groups as regards the clinical data. These findings are in agreement with our result Sohrabvand et al., 2006 [17]; Bjelica et al., 2016 [18] and El Omda et al., 2018 [16]. In the current study, we found that as regards ovulation rate in CC group showed ovulation rate was 55\%, 70\% and $90 \%$ of cases in first, second and third cycles respectively and letrozole group showed ovulation rate in $60 \%, 80 \%$ and $85 \%$ of cases in first, second and third Cycles respectively, with no statistically significant difference between both groups.

The results are in agreement with Kar survey in which the ovulation rate was $73.08 \%$ in the letrozole group and $60.78 \%$ in the CC group, which was not statistically significant [19] .Moreover, this is in agreement with Badawy and associates found [20].

In the present investigation, we found that the total number of follicles mean follicular measurement and the number of follicles > $18 \mathrm{~mm}$, had no factually critical contrast between CC and Letrozole groups at the first, second or third cycles. As the number of follicles in CC group was $1.24 \pm 0.48$ at the first cycle, elevated to $1.31 \pm 0.71$ at the second cycle and $1.42 \pm 0.64$ at the third cycle and in letrozole group was $1.33 \pm 0.52$ at the first cycle, elevated to $1.37 \pm 0.75$ at the second cycle and $1.40 \pm 0.70$ at the third cycle. The mean follicular diameter in CC group, was $18.38 \pm 2.03 \mathrm{~mm}, 17.49 \pm 2.45 \mathrm{~mm}$ and $19.12 \pm 3.21 \mathrm{~mm}$ at the first, second or third cycles respectively, while in letrozole group, it was $17.96 \pm 1.97 \mathrm{~mm}, 17.62 \pm 2.18 \mathrm{~mm}$ and $18.93 \pm 3.06 \mathrm{~mm}$ at first, second or third cycles. The number of follicles $>18 \mathrm{~mm}$ in CC group was $1.02 \pm 0.48,0.95 \pm 0.49$, and $1.24 \pm 0.43$ at the $1 \mathrm{st}, 2 \mathrm{nd}$ and $3 \mathrm{rd}$ cycles respectively, while in letrozole group, it was $1.11 \pm 0.50,1.03 \pm 0.54,1.16 \pm 0.53$ at first, second or third cycles.

In agreement with this result, El Omda and colleagues found that the mean number of follicles larger than $18 \mathrm{~mm}$ in the CC group, was $1.25 \pm 0.58$ at the first cycle, elevated to be $1.32 \pm 0.95$ at the second cycle, and to $1.44 \pm 0.70$ at the third cycle. In the letrozole group, the mean number of follicles larger than $18 \mathrm{~mm}$ was $1.36 \pm 0.61$ at the first cycle, elevated to $1.39 \pm 0.99$ at the second cycle and finally to $1.43 \pm 0.83$ at the third cycles [16]. Also, our results are in harmony with $\mathrm{Hu}$ et al., study, in which the number and the size of mature follicles were similar between both groups. In the letrozole group, $86 \%$ of patients developed mature follicles, whereas $72 \%$ of patients in CC which was statistically insignificant [21]. Similarly, Bjelica and fellows studied 60 moderately obese women with PCOS, treated with either clomiphene citrate-metformin 31 patients or letrozolemetformin combinations 29 patients. They found that the number of follicles that $>18 \mathrm{~mm}$ did not show a statistically significant difference between the two groups, which is in agreement with our results [18].

Contrariwise, AlFozan and co-workers found that the total numbers of follicles during stimulation were similar between the Letrozole and CC groups ( $5.5 \pm 0.4$ in the letrozole group, $4.8 \pm 0.3$ in the CC group). The number of follicles $>14 \mathrm{~mm}$ and $>18 \mathrm{~mm}$ was significantly higher in the letrozole group [22].

In the existing study, there was an increment in the endometrial thickness in Letrozole than CC group (5.84 \pm 0.59 versus $7.91 \pm 0.71$ $\mathrm{mm})$ in the first month, $(6.42 \pm 0.89$ versus $9.74 \pm 0.68)$ in the subsequent month and $(7.16 \pm 1.01$ versus $10.11 \pm 0.93)$ in the third month (P- esteem 0.001). What's more, we found that the total 
endometrial thickness more great in the letrozole group than the CC group which was $(6.48 \pm 0.93)$ in the CC group and $(9.25 \pm 0.84)$ in letrozole group with measurably insignificant distinction.

On the contrary to the current outcomes, Bjelica and associates found that the endometrium was thicker in the group accepting letrozole than in that getting clomiphene citrate was $8.9 \pm 1.7 \mathrm{~mm}$, versus 6.3 $\pm 1.3 \mathrm{~mm}$, separately with a statistically significant difference. [18].

Samani et al. found an insignificant increase in endometrial thickness on the day of HCG administration in the letrozole group [23].

Likewise, Sohrabvand and co-workers [17]. looking at the adequacy of consolidated metformin-letrozole versus metformin-clomiphene citrate in 60 PCO infertile ladies arbitrarily partitioned into letrozole group ( 29 patients) and metformin-clomiphene group (30 patients) found that mean endometrial thickness upon the arrival of HCG administration was significantly less in subjects taking clomiphene citrate than the individuals who got letrozole $(0.55 \pm 0.28$ versus 0.82 $\pm 0.13 \mathrm{~cm}$ ). These results also, match those reported by Mitwally et al [7].

In concurrence with our outcomes, Kar (2012) found no measurably critical distinction between endometrial thicknesses (CC 7.61

\pm 1.96 , letrozole $7.65 \pm 2.10$ ), on day of HCG administration [19]. Additionally, in the study performed by Al-Fozan and associates (2004), no significant difference in the endometrial thickness was found between Letrozole and CC groups $(7.1 \pm 0.2 \mathrm{~mm}$ in the letrozole gathering, $8.2 \pm 5.9 \mathrm{~mm}$ in the CC gathering) [22].

The investigation of Sammour and co-workers, found that patients getting the aromatase inhibitor had expanded endometrial thickness contrasted and those accepting CC (5.5 mm in letrozole versus 5.4 $\mathrm{mm}$ in CC) however, but the difference was statistically insignificant [24].

In the current investigation as respects progesterone level, there was a statistically significant increment in progesterone level in the group getting letrozole than in that accepting CC. In letrozole group, progesterone values were $8.76 \pm 0.52,8.95 \pm 0.51$ and $9.19 \pm 0.52$ at the first, second and third cycles respectively, while in CC group, the equivalent values were $8.01 \pm 0.98,8.29 \pm 0.87,8.37 \pm 0.84$ at first, second and third cycles respectively with a statistically significant difference.

The previously mentioned outcome concerning progesterone disagrees with those of Abu Hashim and colleagues who found that progesterone increased significantly in patients getting clomiphene Citrate than in those accepting letrozole $(11.4 \pm 1.2 \mathrm{ng} / \mathrm{ml}$ versus 7.3 $\pm 0.9 \mathrm{ng} / \mathrm{ml}$ respectively) [25]. On other hands the investigation of Elsedeek and Elmaghraby who found that mid-luteal progesterone was significantly lower in CC group [26].

In the ongoing study we insignificant increase in the pregnancy rate among letrozole than CC users. Pregnancy occurred in 13/60 in the CC group and 15/60 in the Letrozole group.

The results are in agreement with Hu and collaborators' study, who showed that the pregnancy rate in the letrozole group was higher than the CC group (20\% versus $14 \%)$ but the difference was statistically not significant [22]. Likewise, Kar studied 103 infertile PCOS women treated either with $5 \mathrm{mg}$ letrozole or $100 \mathrm{mg}$ CC daily starting day 2 to day 6 of the menstrual cycle. There was no statistically significant difference between both groups as regard pregnancy rate which was $7.84 \%$ in the CC group \& $21.56 \%$ in the letrozole group [19].

Furthermore, AbuHashim and associates found that pregnancy occurred in 14, $7 \%$ in the letrozole group and $14,4 \%$ in CC-group with no statistically significant difference between both groups regarding the pregnancy rate [22].

Metformin caused symptoms as gastritis and nausea in 5\% of our patients who received either CC or Letrozole. The frequency of an event of reactions in the present investigation was lower than that saw by Heard et al., 2002 [27].study on 48 anovulatory PCO patients which was $39 \%$.

Conflicts of interest: The authors declare they have no conflicts of interest.

\section{References}

1. Sereepapong W, Suwajanakorn S, Triratanachat S, Sampatan-ukul P, Pruksananonda K. (2000). Impacts of clomiphene citrate on the endometrium of routinely cycling ladies. Fertil Steril, 73:287-291.

2. Massai MR, de Ziegler D, Lesobre V, Bergeron C, Frydman R and Bouchard P. (1993). Clomiphene citrate influences cervical bodily fluid and endometrial morphology autonomously of the adjustments in plasma hormonal levels initiated by various follicular enrollment. Fertil Steril, 59:1179-1186.

3. Mitwally MF, Biljan MM and Casper RF. (2005). Pregnancy result after the utilization of an aromatase inhibitor for ovarian incitement. Am J Obstet Gynecol, 192(2):381-386?

4. Goswami SK, Das T, Chattopadhyay R, Sawhney V, Kumar J, Chaudhury K, Chakravarty BN and Kabir SN. (2004). a randomized single-dazzle controlled preliminary of letrozole as a minimal effort IVF convention in ladies with poor ovarian reaction: a starter report. Murmur Reprod, 19 (9):2031-2035.

5. Haynes BP, Dowsett M, Mill operator WR, Dixon JM and Bhatnagar AS. (2003) The pharmacology of letrozole, J. Steroid. Biochem, Mol. Biol. 87: 35-45.

6. Fisher SA, Reid RL, Van Vugt DA and Casper RF. (2002). A randomized twofold visually impaired examination of the impacts of clomiphene citrate and the aromatase inhibitor letrozole on ovulatory work in typical ladies. Fertil. Steril, 78: 280-285

7. Mitwally MFM and Casper RF. (2001). Single portion organization of the aromatase inhibitor, letrozole: a straightforward and helpful successful strategy for ovulation enlistment, Fertil. Steril, 76 (Suppl. 1): S94-S95.

8. Masters SB. (2009). Hypothalamic and pituitary hormones, in: Katzung BG, Experts SB, Trevor AJ. (Eds.): Fundamental and Clinical Pharmacology, eleventh ed., vol. 37, McGrawSlope, pp. 643-663.

9. Haas J and Bentov Y. (2017). Should metformin be incorporated into richness treatment of PCOS patients? Therapeutic Theories, 100: 54-58.

10. Rowan JA, Hague WM, Gao W, Battin MR, Moore MP, Mi GTI. (2008). Metformin versus insulin for the treatment of gestational diabetes. N Engl J Medications, 358 (19): 200315.

11. Rui Wang $\mathrm{R}$ and Mol BJ. The Rotterdam criteria for polycystic ovary syndrome: evidence-based criteria? Human Reproduction, Vol.32, No.2 pp. 261-264, 2017

12. Farshchian N, Nezhad ST, and Kamangar PB. (2018). the 
combination of letrozole and metformin has a better therapeutic effect on uterine and ovarian arteries in PCOS patients than the combination of clomiphene citrate and metformin. AMJ, 11(6):326-330

13. Leon Speroff. (1999). Clinical Gynaecologic Endocrinology and Infertility, Lippinicon Williams \& Wilkins, 12: 490.

14. Greenblatt RB, Barfield WE, Jungck EC and Ray AW. (1961). Induction of ovulation with MRL/41.JAMA, 178:101-5.

15. Buzdar AU, Robertson JF, Eiermann W and Nabholtz JM. (2002). an overview of the pharmacology and pharmacokinetics of the newer generation aromatase inhibitors anastrozole, letrozole, and exenmestrane.Cancer, 95:2006- 2016.

16. El Omda FA, Abd El Fattah AT, Hashish MA and Khalil MA. (2018). A Randomized Trial of Combined Letrozole with Metformin Versus Clomiphene Citrate with Metformin in Polycystic Ovary (PCOS) patients. The Egyptian Journal of Hospital Medicine, 72(4), 4382-4388.

17. Sohrabvand F, Ansari SH and Bagheri M. (2006). Efficacy of combined metformin- letrozole in comparison with metformin-clomiphene citrate in clomiphene- resistant infertile women with polycystic ovarian disease, Human Reproduction, 21(6), 1432-1435.

18. Bjelica A, Trninić-Pjević A, Mladenović-Segedi L, Cetković N and Petrović D. (2016). Comparison of the efficiency of clomiphene citrate and letrozole in combination with metformin in moderately obese clomiphene citrate resistant polycystic ovarian syndrome patients. Srp Arh Celok Lek, 144(3-4):146- 150.

19. Kar S. (2012). Clomiphene Citrate or letrozole as first-line ovulation induction drug in infertile PCOS women: A prospective randomized trial. J Hum Reprod Sci, 5(3):262265.

20. Badawy A, Abdel Aal I and Abulatta M. (2007). Clomiphene citrate or letrozole for ovulation induction in women with polycyctic ovarian syndrome: a prospective randomized trial. J.fertnstert, 02.062. Fertil Steril.2009; 92(3); 849-852.
21. HU S, YU Q, Wang Y, Wang M, Xia W and Zhu C. (2018). Letrozole versus clomiphene citrate in polycyctic ovary syndrome: a meta-analysis of randomized controle trials. Arch Gynecol Obstet, 297(5):1081-1088.

22. Al-Fozan H, Al-Khadouri M, Tan SL and Tulandi T. (2004). A randomized trial of letrozole versus clomiphene citrate in women undergoing superovulation. Fertil. Steril, 82 (6): 1561-1563.

23. Samani F, Farzadi L, Nezami N, Tarzamni M. (2009). Endometrial and follicular development following letrozole intervention in unex-plained infertile patients failed to get pregnant with clomiphene citrate. Arch Gynecol Obstet, 280(2):201-205.

24. Sammour A, Biljan MM, Tan SL, andTulandi T. (2001). Prospective randomized trial comparingthe effects of letrozole (LE) and clomiphene citrate (CC) on follicular development, endometrial thickness and pregnancy rate in patients undergoing super-ovulation prior to intrauterine insemination (IUI). Fertil Steril, 76(3), (1): S110.

25. Abu Hashim H, Shokeir T and Badawy A. (2012). Letrozole Versus combined Metformin and clomiphene citrate for ovulation induction in clomiphene-resistant women with polycystic ovary syndrome: a randomized control trial. Fertil Steril, 94:1405-1409.

26. Elsedeek MS and Elmaghraby HAH. (2011). Predictors and characteristics of letrozole induced ovulation in comparison with clomiphene induced ovulation in comparison with clomiphene induced ovulation in anovulatory PCO women Middle East Fertility Society Journal, 16(2),125-130.

27. Heard MJ, Pierce A, Carson SA and Buster JE. (2002). Pregnancies following use of metformin for ovulation induction in patients with polycystic ovary syndrome. Fertil Steril, 77(4):669-673.
This work is licensed under Creative Commons Attribution 4.0 License

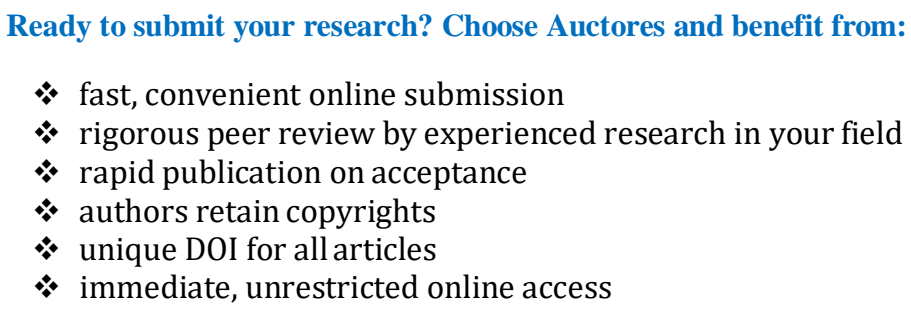

Ready to submit your research? Choose Auctores and benefit from:

* fast, convenient online submission

* rigorous peer review by experienced research in your field

* rapid publication on acceptance

* authors retain copyrights

* unique DOI for all articles

* immediate, unrestricted online access

At Auctores, research is always in progress.

Learn more www.auctoresonline.org/journals/obstetrics-gynecologyand-reproductive-sciences 